\title{
A Systematic Review of Antonovsky's Sense of Coherence Scale and Its Use in Studies Among Nurses: Implications for Psychiatric and Mental Health Nursing
}

\author{
Antonovsky Bütünlük Duygusu Ölçeği ve Hemşirelik Araştırmalarında Kullanımının \\ Sistematik Incelemesi: Ruh Sağlığı ve Psikiyatri Hemşireliği Açısından Anlamlar
}

\author{
Martin WARD, ${ }^{1}$ Michael SCHULZ, ${ }^{2}$ Dirk BRULAND, ${ }^{3}$ Michael LOHR ${ }^{3}$
}

\section{SUMMARY}

Objectives: Antonovsky's salugenetic model focuses on factors that promote health and well-being. The objectives of this paper were to review the existing research literature related to Antonovsky's Sense of Coherence Scale (SOC) and establish implications for psychiatric and mental health nurses.

Methods: Electronic databases were searched with selected studies compared for sample, sample size, study designs and basic results. Cross-sectional studies were reviewed for correlations between personality traits, stress, burnout, disease-scales, job satisfaction and the SOC scale, with Intervention studies used to establish the impact of training on the SOC.

Results: The review discovered serious methodological difficulties, including interpretations of Antonovsky's philosophical values and the apparent use of the SOC scales as a measure of disease absence.

Conclusion: The review was able to draw important conclusions for psychiatric and mental health nurses (PMHNs) related to stress, burnout, dealing with psychiatric emergencies and the selection of new recruits to the profession.

Key words: Antonovsky; burnout; psychiatric emergencies; psychiatric and mental health nursing; salutogenesis; Sense of Coherence scale; stress.

\section{ÖZ}

Amaç: Antonovsky'nin salutogenik modeli sağlık ve iyilik halini destekleyen faktörler üzerine odaklanmaktadır. Bu makalenin amaçları Antanovsky'nin Bütünlük Duygusu Ölçeğine (SOC) ilişkin mevcut araştırma literatürünü gözden geçirmek, psikiyatri ve akıl sağlığı dallarında çalışan hemşireleri ilgilendiren çıkarımları belirlemektir.

Gereç ve Yöntem: Elektronik veri tabanlarında örnekler, örneklem büyüklüğü, çalışma tasarımları ve temel sonuçlar açısından karşılaştırmalı seçili çalışmalar araştırılmıştır. Enine kesitsel çalışmalar, kişisel özellikler, stres, tükenmişlik, hastalık ölçekleri, meslek memnuniyeti ve SOC ölçeği arasındaki korelasyonlar gözden geçirilmiş, eğitimin SOC üzerine etkisini belirlemek için girişimsel çalışmalar kullanılmıştır.

Bulgular: Bu derleme Antonovsky'nin felsefi değerlerini yorumlamada ve hastalık yokluğunun bir ölçümü olarak SOC ölçeklerinin görünürdeki kullanımı dahil olmak üzere ciddi metodolojik zorluklar olduğunu ortaya çıkartmıştır.

Sonuç: Bu derleme psikiyatri ve akıl sağlığı alanlarında çalışan hemşirelerde stres, tükenmişlik, psikiyatrik acillerle başa çıkma ve mesleğe yeni katılacakların seçimi açısından önemli sonuçlara varabilmiştir.

Anabtar sözcükler: Antonovsky; tükenmişlik; psikiyatrik aciller; psikiyatri ve akıl sağlı̆̆ı hemșireliği; salutogenez; Bütünlük Duygusu ölçeği; stres.

\section{Introduction}

In the mid 1970's Aaron Antonovsky, an American sociologist and academic, was considering studies into various forms of health status and began particularly to question how individuals could stay healthy when exposed to stress. In contrast to the traditional pathogenesis model which fo-

${ }^{1}$ Faculty of Health Sciences, University of Malta, Msida, Malta; 2Department of Nursing, Diaconical University of Applied Sciences, Bielefeld, Germany;

${ }^{3}$ Department of Nursing, University of Bielefeld, Germany

Correspondence: Martin WARD, M.D.

e-mail: mwoxford@aol.com

Psikiyatri Hemşireliği Dergisi 2014;5(2):61-71

Journal of Psychiatric Nursing 2014;5(2):61-71

Doi: $10.5505 /$ phd.2014.28291

Submitted: March 09, 2014 Accepted: June 22, 2014 cuses on factors that cause disease, the salutogenetic model he developed considered the factors which assist health and wellbeing. For Antonovsky people are not ill or healthy, but move between these two extremes; whilst health and illness themselves are not seen as polemic but building on a healthease/dis-ease continuum. ${ }^{[1-3]}$ In recent years, as the awareness of the impact of stress on peoples' lives has become more apparent, the conception of salutogenesis has gained in importance.

The key part of Antonovsky's theory is what he refers to as the Sense of Coherence (Antonovsky 1979), which includes three components: sense of comprehensibility, sense of manageability and sense of meaningfulness. A strong Sense of Coherence (SOC) contributes to maintain and assist health because it enables a person to mobilize internal resources and build up resistance against stressors. ${ }^{[4]}$ Stressors, formulated by Antonovsky following Lazarus, ${ }^{[5]}$ are stimuli which can 
be internal or external, which in themselves do not lead to distress or affect health in principle. To detect and to put the model into practice, Antonovsky ${ }^{[2]}$ developed a specific questionnaire; the SOC scale. It measures the Sense of Coherence as a disposition which generates and supports health.

The profession of nursing contains a lot of stressors ranging from high workload to permanent confrontations with sorrows, each of which can lead to work-related stress. Nursing studies from around the world show strong agreement that work-related stress influences the potential for both physical (such as musculoskeletal problems) and mental impairment (including minor psychiatric morbidity, specifically, depression) (ILO 2000). Perhaps more significantly studies also show such stress negatively influences work quality by reducing nursing care outcomes. For example, Aiken, Clarke, Sloane, Sochalski and Silber ${ }^{[6]}$ showed a direct correlation between the risk of burnout or professional dissatisfaction with patient mortality times following discharge from hospital. This is perhaps even more alarming when considered against the backdrop of a study of 10 European countries reporting more than $10 \%$ of all practising nurses wanted to leave their. [7] To be of value studies that analyse Antonovsky's Sense of Coherence scale for nursing must take account of those factors or work frameworks that promote positive wellbeing. The aim of this paper, therefore, is to describe the current status of international research pertaining to the Sense of Coherence scale related to nurses, and specifically, psychiatric and mental health nursing (PMHN), with the main findings and results used to draw conclusions about the profession's mental health promotion at work.

\section{Materials and Methods}

This paper was predicated on a targeted search and review of the existing body of published research-based quantitative literature in the English and German languages pertaining to the use of the Sense of Coherence Scale and all nurses. Excluded from the review were Editorials, qualitative studies, unpublished and unregistered papers found in other reference lists, Doctoral thesis and postgraduate papers.

The search strategy was based on an electronic exploration in the following databases; Pubmed, Medline, Medpilot (all databases), Psycinfo, DIMDI (all databases), Cinahl, Social Sciences Citation Index (All databases). Searches of the databases were performed using the search keywords; nurse* AND „Sense of Coherence“, nurse* AND soc, nurse* AND antonovsky, nurse* AND saluto*, "health care workers” AND „Sense of Coherence“, "health care workers” AND soc, "health care workers" AND Antonovsky, and "health care workers" AND saluto*. Research was also sought under the old name for the SOC scale; 'Orientation to Life Questionnaire' and its shortcut "OLQ" in Pubmed, with no results found. Reference lists were browsed to identify additional papers. After the adjustment for double listings in the databases 21 papers met the inclusion criteria on March 4th 2009. A strict protocol was used to profile each paper. This included biographical data such as the sample (nurses/health care workers): sample size, mean age and gender; the version of the SOC questionnaire used (long or short form), the SOC means as well as the standard deviation, the research method and use of additional questionnaires, key results and limitations of the study plus references (see Table 1 and 2 for details).

\section{Sample and Sample Size}

The search conducted for the group of 'nurses' was somewhat limited in terms of match. Every study had a reference to nurses, but they are all in different fields of operation. For example, descriptive fields included: unemployed nurses, student nurses, ambulant nurses, nurses on a ward providing care for patients with psychotic disorders, or borderline personality disorders. Furthermore, there were highly deviant or single case studies being very different to the other studies such as, full time working nurses ${ }^{[8]}$ or nurses having one or more children. ${ }^{[9]}$

Most of the studies were undertaken using female nurses as the sample thus research on gender differences was difficult to locate. One study in particular ${ }^{[10]}$ specifically excluded four male subjects so that data would not be skewed by this relatively small gender mix. Sample size ranged from $22>$ 721 subjects. Ten out of 21 studies had a sample size under 100 subjects, whilst six were fewer than 50 . The sample size was mentioned as being critical in some of the studies ${ }^{[11]}$ though it is not clear why this was the case. Only three of the reported studies had samples that exceeded 250.

\section{Review Sample}

Ten of the included studies used the 13 items SOC scale (short form) and 10 of the studies used the 29 items scale (long form) whilst one ${ }^{[12]}$ did not specify the number of items. However, in this study the old name for the SOC scale was used; "Orientation to Life Questionnaire", therefore it was reasonable to conclude that the 29 items version was used. Although there were roughly similar numbers of studies exploring the use of short and long forms of the questionnaire it was noted that prior to 2000 all research had been conducted on the long version, but following this date all research was carried out using the short form of the questionnaire. No exact explanation could be found for this except that following the development of the shortened version the literature generally appeared to regard this as the more effective form.

Of the 21 papers used in this study, 16 were of a cross sectional nature with the SOC being tested for correlations to other instruments measuring factors such as burn- 
Table 1. Included studies detail

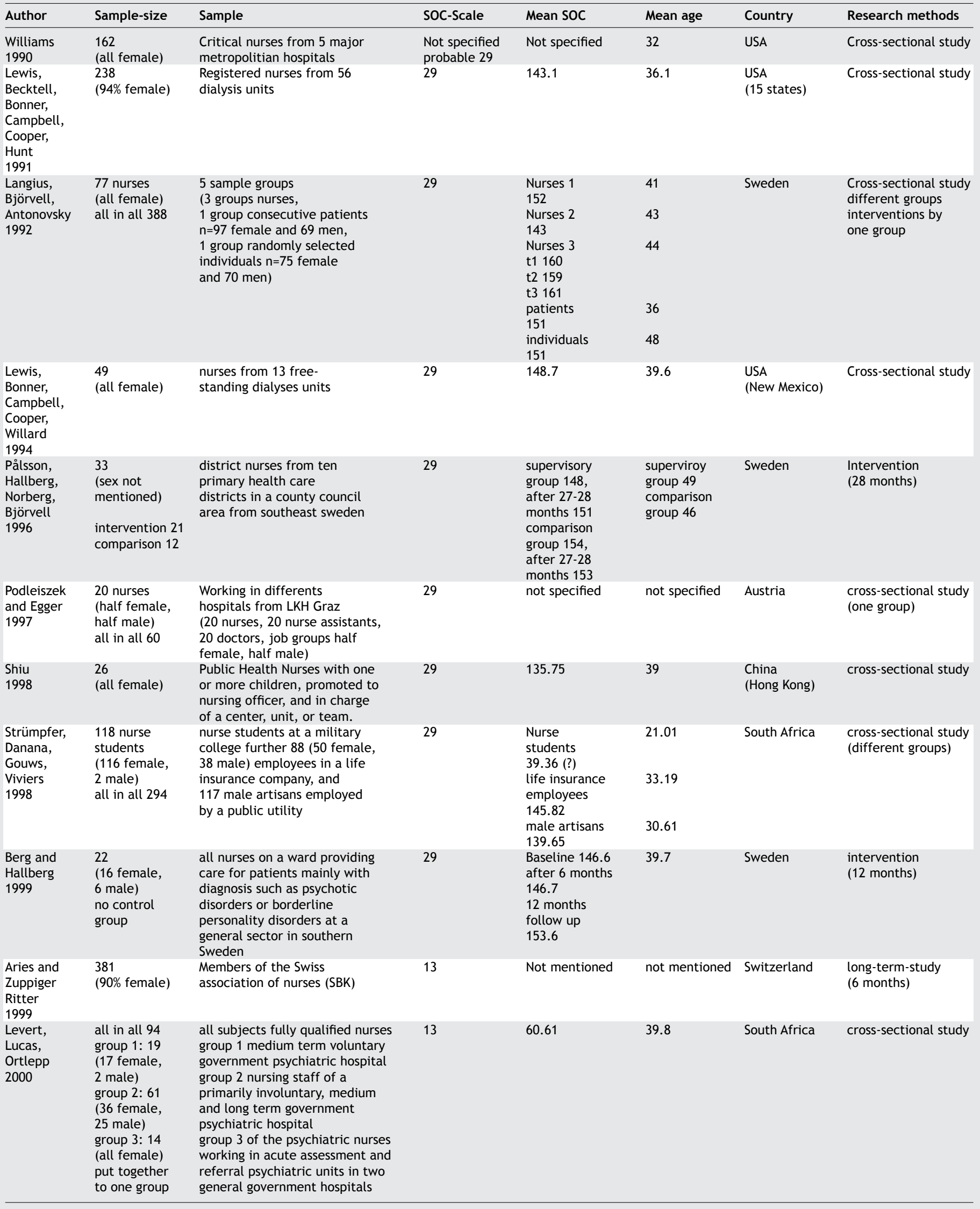


Table 1. Included studies detail (continuation)

\begin{tabular}{|c|c|c|c|c|c|c|c|}
\hline Author & Sample-size & Sample & SOC-Scale & Mean SOC & Mean age & Country & Research methods \\
\hline $\begin{array}{l}\text { Michael } \\
\text { and } \\
\text { Jenkins } \\
2001\end{array}$ & $\begin{array}{l}233 \\
(225 \text { female, } \\
8 \text { male) }\end{array}$ & $\begin{array}{l}\text { nurses working in areas within } \\
\text { operating suites }\end{array}$ & 13 & 66.75 & 41 & $\begin{array}{l}\text { Western } \\
\text { Australia }\end{array}$ & cross-sectional study \\
\hline $\begin{array}{l}\text { Tselebis, } \\
\text { Moulou; } \\
\text { Ilias } \\
2001\end{array}$ & $\begin{array}{l}79 \\
(62 \text { female, } \\
17 \text { male })\end{array}$ & $\begin{array}{l}\text { nurses in general internal } \\
\text { medicine, general surgery and } \\
\text { respiratory medical ward in one } \\
\text { of the largest hospitals in Greece }\end{array}$ & 13 & 63.6 & 34.7 & Greece & cross-sectional study \\
\hline $\begin{array}{l}\text { Cilliers } \\
2003\end{array}$ & $\begin{array}{l}105 \\
\text { (all female) }\end{array}$ & $\begin{array}{l}\text { registered general nurses, three } \\
\text { year nursing diploma and five } \\
\text { years nursing experience }\end{array}$ & 29 & 141.28 & $\begin{array}{l}\text { Range } \\
28 \text { to } 57\end{array}$ & $\begin{array}{l}\text { South Africa } \\
\text { (Gauteng } \\
\text { Province) }\end{array}$ & cross-sectional study \\
\hline $\begin{array}{l}\text { Yam and } \\
\text { Shiu } \\
2003\end{array}$ & $\begin{array}{l}29 \\
\text { (all female) }\end{array}$ & $\begin{array}{l}\text { full time working critical care } \\
\text { nurses in public and private } \\
\text { hospitals }\end{array}$ & 13 & not specified & 32 & $\begin{array}{l}\text { China } \\
\text { (Hong Kong) }\end{array}$ & cross-sectional study \\
\hline $\begin{array}{l}\text { Heyns, } \\
\text { Venter, } \\
\text { Esterhuyse, } \\
\text { Bam, } \\
\text { Odendaal } \\
2003\end{array}$ & $\begin{array}{l}226 \\
\text { (sex not } \\
\text { mentioned) }\end{array}$ & $\begin{array}{l}\text { Nurses from } 21 \text { institutions } \\
\text { involved in the care of } \\
\text { Alzheimer's patients ( } 66 \% \text { no } \\
\text { professional qualification) }\end{array}$ & 29 & 130.57 & 38 & South Africa & cross-sectional study \\
\hline $\begin{array}{l}\text { Leino-Loison, } \\
\text { Gien, } \\
\text { Katajisto, } \\
\text { Välimäki } \\
2004\end{array}$ & $\begin{array}{l}183 \\
\text { (97\%female) }\end{array}$ & unemployed nurses & 13 & 60.19 & 32.5 & Finland & cross-sectional study \\
\hline $\begin{array}{l}\text { Höge and } \\
\text { Büssing } \\
2004\end{array}$ & $\begin{array}{l}160 \text { nurses } \\
\text { all in all } 205 \\
\text { ( } 78.9 \% \text { female) }\end{array}$ & $\begin{array}{l}\text { hospitals employees, Nurses } \\
(160 / 78.4 \%) \text {, phyisicians } \\
(20 / 9.8 \%) \text { and medical laboratory } \\
\text { technicans ( } 24 / 11.8 \%) \\
\text { from two hospitals }\end{array}$ & 13 & $\begin{array}{l}\text { nurses } 68.1 \\
\text { physicans } \\
75.06 \\
\text { medical } \\
\text { technicans } 70.65\end{array}$ & $\begin{array}{l}\text { whole } \\
\text { sample } \\
34.1\end{array}$ & Germany & $\begin{array}{l}\text { cross-sectional study } \\
\text { (one group) }\end{array}$ \\
\hline $\begin{array}{l}\text { Shimizu, } \\
\text { Kubota, } \\
\text { Mishima, } \\
\text { Nagata } \\
2004\end{array}$ & $\begin{array}{l}258 \\
\text { (all female, } \\
4 \text { male in } \\
\text { intervention } \\
\text { group excluded) }\end{array}$ & $\begin{array}{l}\text { registered nurses working at } \\
\text { Japanese hospitals } \\
\text { ( } 62 \text { intervention and } 196 \\
\text { reference group) }\end{array}$ & 13 & $\begin{array}{l}\text { intervention: } \\
\text { baseline } 57.4 \\
\text { follow up } 59.6 \\
\text { reference: } \\
\text { baseline } 52.7 \\
\text { follow up } 54.2\end{array}$ & $\begin{array}{l}\text { Intervetion } 44 \text {, } \\
\text { Refe-rence } \\
27,8\end{array}$ & Japan & $\begin{array}{l}\text { intervention study } \\
\text { ( } 6 \text { months) }\end{array}$ \\
\hline $\begin{array}{l}\text { Höge } \\
2005\end{array}$ & $\begin{array}{l}721 \\
\text { (91.9\% female) }\end{array}$ & $\begin{array}{l}\text { ambulant nurses of } 97 \text { nursing } \\
\text { service }\end{array}$ & 13 & 64.81 & 41.6 & Germany & cross-sectional study \\
\hline $\begin{array}{l}\text { Engström, } \\
\text { Ljunggren, } \\
\text { Lindquist, } \\
\text { Carlsson } \\
2005\end{array}$ & $\begin{array}{l}33 \\
(31 \text { female, } \\
2 \text { male) } \\
\text { Experimental } 17 \\
\text { Control } 16\end{array}$ & $\begin{array}{l}\text { staff members of a residental } \\
\text { home for persons with dementia } \\
\text { (registerd nurses, auxiliary nurses, } \\
\text { licensed practical nurses) }\end{array}$ & 13 & $\begin{array}{l}3 \text { ratings } \\
\text { Experimental } \\
\text { group: } \\
72,69,75 \\
\text { Control group: } \\
68,69,65\end{array}$ & 41 & Sweden & $\begin{array}{l}\text { interventions } \\
\text { (12 months) }\end{array}$ \\
\hline
\end{tabular}

out and stress, and one ${ }^{[13]}$ which checked internal and testretest reliability. This study used one nurses sample group, which uniquely completed the questionnaires at three intervals (first day of a selective research training course, one week later, and finally after two months). The cross sectional studies used varied forms of nursing samples, from specialist areas of work to individual hospitals, for example critical care nurses, ${ }^{[12]}$ or from one workplace with different areas of work, such as diverse groups of nurses from one of the largest hospitals in Greece. ${ }^{[14]}$ Four of the sixteen studies had more than one sample and/or samples with more than one role or job. Languis, Björvell and Antonovsky ${ }^{[13]}$ had five sample groups (three nurse groups, one group of consecutive patients and one group of randomly selected individuals). Strümpfer, Danana, Gouws and Viviers ${ }^{[15]}$ separately analysed nursing students, employees from a life insurance company and artisans (male only). Hospital employees (nurses, physicians and medical laboratory technicians) from two hospitals were also analysed separately by Höge and Büssing. ${ }^{[16]}$ Podleiszek and Egger ${ }^{[17]}$ investigated 20 nurses, 20 nursing assistants and 20 doctors, with an equal number of males to females, in one total sample. One further study ${ }^{[18]}$ collected data over a six month period but did not include intervention activity against which to measure this.

Additionally, four intervention studies were located. Three of these were undertaken in Sweden, ${ }^{[19-21]}$ the fourth in Japan. ${ }^{[10]}$ Shimizu ${ }^{[10]}$ tested the effect of a two-day Assertiveness Training programme with 94 nurses in the intervention group, and 315 nurses in a control group. All nurses received the questionnaire before the training started and once again six months later. Two of the Swedish studies used different procedures to test the effects of systematically regulated clinical supervision. The first ${ }^{[19]}$ collected data from 33 district nurses in 10 primary health care districts before giving training, and 
Table 2. Further used questionnaires and basic results

\begin{tabular}{|c|c|c|}
\hline Author & Further used questionnaires & Basic results \\
\hline $\begin{array}{l}\text { Williams } \\
1990\end{array}$ & $\begin{array}{l}\text { Schedule of Recent Experience (SRE), } \\
\text { Global Inventory of Stressors, } \\
\text { Personal View Survey (PVS), } \\
\text { Seriousness of Illness Rating Scale (SIRS), }\end{array}$ & $\begin{array}{l}\text { Direct effects of Global Stress }(r=-0.562) \text {, Event Stress }(r=-.273) \text {, Hardiness } \\
(r=.502) \text { and Illness }(r=-.302) \text { most strongly correlated, SOC is a more powerful } \\
\text { mediator of stress and illness than hardiness }\end{array}$ \\
\hline $\begin{array}{l}\text { Lewis, } \\
\text { Becktell, } \\
\text { Bonner, } \\
\text { Campbell, } \\
\text { Cooper, }\end{array}$ & $\begin{array}{l}\text { Nursing Stress Scale (NSS), Maslach Burnout } \\
\text { Inventory (MBI), }\end{array}$ & $\begin{array}{l}\text { Men shows lower SOC-scores than women, significant correlation with overall } \\
\text { stress }(r=-0.39) \text {, and subscales of burnout (Emotional Exhaustion } r=-.57 \text {, } \\
\text { Depersonalisation } r=-.54 \text {, Personal Accomplish } r=.53) \text {, no relationship between } \\
\text { overall SOC and age, marital status, educational level, position, years in nursing, } \\
\text { number of patients or shift unit, shift lengths or hours worked per week }\end{array}$ \\
\hline
\end{tabular}

Hunt

1991

Langius,

Björvell,

Antonovsky

1992

Self Motivation Inventory (SMI), Karolinska Scales of Personality (KSP)

Lewis,

Bonner,

Campbell,

Cooper,

Willard

1994

Pålsson,

Hallberg,

Norberg,

Björvell

1996

Podleiszek

and Egger

1997

Myers-Briggs-Type Indicator, Perceived tress Scale, Nursing Stress Scale, Coping Resources Inventory, Maslach Burnout Inventory,

Karolinska Scales of Personality (KSP), Burnout Measure, Empathy Construct Rating Scale (ECRS),

Shortform Fragebogen zu Lebenszielen und zur Lebenszufriedenheit (FLL) [Questionnaire for aim in life and lifesatisfaction], subjective rating-items for social status, questions to sociodemographic status

$\begin{array}{ll}\text { Shiu } & \text { Experience sampling method (ESM), } \\ 1998 & \end{array}$

Strümpfer, Job Satisfaction Scale (Warr et al.), Danana, Positive affectivity (PANAS PA) and Gouws, negative affectivity (PANAS NA), Viviers personality from self and peer ratings 1998 (McCC Extraversion and McCC Neuroticism), Neutral Objective Satisfaction

Questionnaire (NOSQ)

Berg and Creative Climate Questionnaire (CCQ), Hallberg Work-Related-Strain-Inventory WRSI, 1999 Satisfaction with Nursing Care and Work Questionnaire (SNCW)

Aries and Demographical questionnaire, Maslach Zuppiger Burnout Inventory (German vision), Ritter Workplace character (Enzmann \& $1999 \quad K$ Kleiber 1989), doctor-nurse-relationship, various job character scales,

Levert, Maslach Burnout Inventory (MBI),

Lucas, Questionnaire work load and Lack of

Ortlepp Collegial support, Questionnaire role

$2000 \quad$ conflict and Role Ambiguity

Michael and Checklist about amount of support

Jenkins

2001

Tselebis, Maslach Burnout Inventory (MBI),

Moulou; $\quad$ Beck's Depression inventory (BDI)

Ilias

2001
SOC questionnaire consistently shows a high level of internal consistency and shows a high level of test-retest reliability, no significant differences between the groups, SMI are scored in reverse to SOC, Detachment, Aggression, Psychasthenia and the inhibtion of Aggression negatively correlated with the SOC (not all significant)

Negative correlations between SOC and personal stress ( $r=-.715)$, and SOC and work stress ( $(.436)$, positive relationship between total coping resources $(r=.667)$ and SOC, negative correlations between Burnout and SOC $(r=.395)$, there were no significant differences in sensing vs. intuitive types or thinking vs. feeling types.

Correlations between burnout $(r=-0.69)$, empathy $(r=0.76)$ and soc, no significant differences found before and after interventions

Men showed a higher level of soc than women, correlations between SOC and FLL, differences job not confirmed, employee management no influence on SOC, The results showed no effect on the sense of coherence for professional category, level of education, work experience, income, and chance to shaping working frameworks. But test persons who are satsified with the chance to shaping working frameworks had a higher sense of coherence than test person who were not.

There was a positive correlation between $\mathrm{SOC}$ and perceived goal progress $(r=0.43)$ and perceived control $(r=0.35)$, Public Health Nurses with higher SOC values had higher positive affects

SOC-scale high correlation with all of the job satisfaction score in every sample, the sense of coherence scale was the only dispositional measure which consistently showed both statistically and practically significant with job satisfaction. Results of the stepwise multiple regression not reported.

A high SOC score correlated with satisfaction (SNCW) $(r=-0.46)$ and with low score of WRSI $(-0.48)$, the results of the correlation was related to work-related strain but not to unsatisfactory working conditions/milieu., there were no significant effects on the SOC based on the intervention Sense of coherence value get tendency more in the sample group with burnout, and tendency lower in the sample group without burnout.

Significant correlations were found between SOC-13 scores and emotional exhaustion and depersonalisation (MBI), the SOC and work load together explained the majority of the variance in emotional exhaustion,

nurses which did not report a traumatic experience have higher SOC-values

Correlations analysis showed that SOC was negatively and strongly correlated with $\mathrm{BDI}$. The SOC scores were correlated with all MBI categories 
Table 2. Further used questionnaires and basic results (continuation)

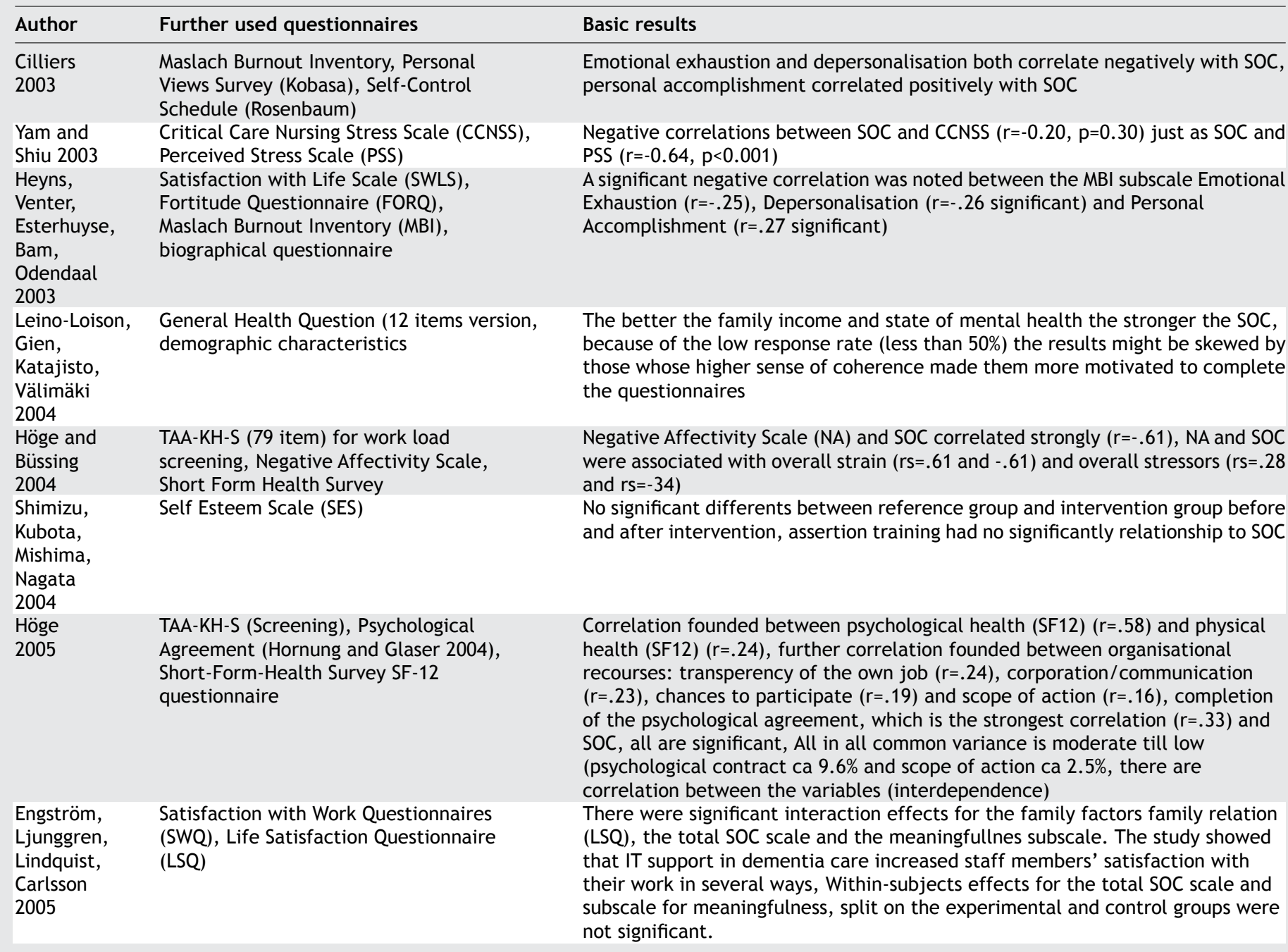

again after 28 months when the intervention was completed. In addition to the intervention group $(n=21)$ there was a control group $(n=12)$. The nurses completed further interviews to gather more information regarding their experiences of the supervision. The second Swedish study ${ }^{[20]}$ evaluated an intervention group $(n=22)$ of psychiatric nurses, without a control group. The nurses completed the questionnaire at the outset of the study, then 6 and twelve months after the intervention. Engström ${ }^{[21]}$ tested the effect of IT-support in dementia care in a residential home. The intervention $(n=17)$ and control $(n=16)$ groups received the questionnaire before the intervention and again at six and 12 month intervals.

\section{Key Findings \\ Quality Criteria}

Languis, Björvell and Antonovsky ${ }^{[13]}$ tested internal consistency and test-retest reliability with a high level described for both. Moreover, the relationship between the SOC and personality traits were also tested. The authors reported that those with strong SOC scores had higher general motivation and less reported hostility, somatic and psychic anxiety. The authors suggested that the SOC scale could be used as a useful instrument, for example, in guiding individualized nursing care. A slightly earlier study ${ }^{[12]}$ tested the information value of Kobasa, Maddi, Puccetti and Zola's ${ }^{[22]}$ concept of personality (Hardiness) compared to Antonovsky's Sense of Coherence, concerning the relationship between stress and illness. It was concluded that the SOC was a more powerful mediator than hardiness.

\section{Burnout}

As part of their study Levert, Marilyn and Ortlepp ${ }^{[23]}$ focused on burnout in PMHNs. Significant correlation was found between SOC and the burnout subscales of emotional 
exhaustion and depersonalisation with additional relationships found between SOC and work load using a multiple regression analyses. The authors concluded that a strong SOC and a manageable work load would be far less likely to generate emotional exhaustion and depersonalisation in these nurses. However, another way of viewing these findings is to suggest that a nurse with a strong SOC would experience fewer stressful situations, and would therefore be more inclined to ask for help when their workload became difficult to manage.

In the study by Tselebis, Moulou and Ilias ${ }^{[14]}$ analysis showed that SOC in nursing staff was correlated with burnout and depression, whilst depression was correlated to a lesser degree with burnout. It was hypothesized that the degree of SOC rendered nurses either vulnerable or resistant to both depression and burnout. In this study, gender, age and years of practice experience showed no correlation to the SOC and the study offered no information about the SOC itself. By contrast, Cilliers ${ }^{[24]}$ attempted to determine the nature of the relationship between burnout and salutogenetic functioning and found correlation between all subscales for burnout and SOC For Cilliers this confirmed the hypothesis that nurses functioning on high levels of SOC would function on low levels of burnout. The author recommended more research for the effects of salutogenetic functioning.

This was further expressed by Heyns, Venter, Esterhuyse, Bam and Odendaal ${ }^{[25]}$ who focused on the relationship between burnout and fortitude among nursing staff. Significant correlation was found between all burnout subscales and SOC. According to the authors demonstrated that Sense of Coherence had a strong association with the absence of symptoms of burnout. However, they failed to identify how the presence of SOC could actively work against the processes of burnout.

\section{Stress}

Yam and Shiu ${ }^{[8]}$ analysed SOC and perceived stress with a sample of Critical Care nurses. According to the authors, $\mathrm{SOC}$ appeared to be a protective factor in relation to stress perceptions arising from the work environment. They recommended that nursing managers use the SOC as a framework to guide in helping nurses develop resistance to stress, though they failed to say how this might be achieved. Höge and Büssing's ${ }^{[16]}$ investigated the specific influences of SOC and negative affectivity on the relationship between work stressors and strain. They found a strong correlation $(r=-0.61)$ between SOC and negative affectivity. According to the authors SOC subsumed relevant personality characteristics such as internality, dispositional optimism and self-efficacy. They also indicated that job position (within the employment hierarchy) had significant positive effects on the SOC.

\section{Stress and Burnout}

In both studies undertaken by Lewis, Lewis, Bonner, Campbell, Cooper and Willard ${ }^{[11]}$ and Lewis, Campbell, Becktell, Cooper, Bonner and Hunt, ${ }^{[26]}$ nurses from dialyses units were the focus of study. The goal in $1992^{[11]}$ was to examine the relationship between work stressors, burnout and SOC. The authors concluded that as the level of stress increased, the SOC had a major effect in mediating the effect of stress on burnout. Noticeable was that men showed a lower SOC than women. However, no relationship was shown between the variables age, marital status, level of education, years of work, job position, numbers of caring patients, hours per shift, shift unit or hours of work per week. In 1994 ${ }^{[26]}$ the aim of their study was to examine the relationship between personality types, personal and work-related stress, coping resources, and SOC. In this study SOC and coping resources were significant predictors of personal and work-related stress as well as burnout. No correlates were found for the personality types with no significant differences in sensing vs. intuitive types, or thinking vs. feeling types concerning SOC.

\section{Working Circumstances}

Podleiszek and Egger ${ }^{[17]}$ studied the psychological aspect of SOC. Their results showed no effect on the SOC for different professional groups, level of education, work experience and income. However, sample members who had influence over the work environment had a higher SOC than those who did not. Men showed a higher SOC than women. Results here can be interpreted as showing that work role was not the main factor for the SOC. Personality dispositions and job satisfaction were the focus for Strümpfer, Danana, Gouws and Viviers. ${ }^{[17]}$ The SOC scale had high correlation with all of the job satisfaction scores in every sample. In addition the SOC scale was the only dispositional measure which consistently showed statistically significant correlation with job satisfaction. According to the authors people's SOC formed either earlier or specifically outside the current work situation and went on to enhance later job satisfaction. They perceived job satisfaction being present when employees made cognitive sense of their workplace, perceived their work as consisting of experiences that were bearable and made emotional and motivational sense of work demands.

Höge ${ }^{[27]}$ studied nurses working in outpatient departments with the focus on psychophysical health. Results of pathway analyses showed that the nurse's perception of fairness had a significant impact on SOC. The author suggested that the development of SOC took place beyond the nurses employment area but also felt there was sufficient evidence in the data to show that organizational arrangements could influence the SOC and the nurse's health. 


\section{Social Circumstances}

These conclusions ${ }^{[27]}$ would appear to support those of an earlier study by ${ }^{[9]}$ where the SOC of public health nurses with one or more children was analysed. Two main results stem from this study. Firstly, there was a positive correlation between SOC and perceived task characteristics. Secondly, that the nurses in the sample who had high a SOC also had higher positive affect as opposed to those with lower SOC values. The author suggested that $\mathrm{SOC}$ as a salutogenetic model helped to cope with the juggling of family and work as well as occupational stress whilst also recognising the positive role of a health-promoting work environment based on good nursing management. Leino-Losion, Gien and Välimäki ${ }^{[28]}$ explored the SOC of unemployed nurses, which was found to be high. Demographic variables such as family income and general state of mental health significantly related to the SOC. A further Finnish study ${ }^{[29]}$ stated that people who exercised twice a week had a stronger feeling of social integration and a higher level of Sense of Coherence.

\section{Work Related Trauma}

For Michael and Jenkins ${ }^{[30]}$ the overarching issue was the effect of social and personal resources at work, related to trauma. Of their respondents, preoperative nurses, those who did not report a traumatic event had the strongest SOC. Two opposite explanations were debated; nurses, with a strong SOC did not sense an event as being as traumatic as nurses with a low SOC, or, conversely, traumatic events influence the SOC. No final conclusions were drawn.

\section{Longitudinal Section Study}

Aries and Zuppiger-Ritter ${ }^{[18]}$ collected data from 1995 at six monthly intervals. Only marginal changes took place in the SOC over time but it was noted that a lower SOC existed in the nurses experiencing burnout against a higher $\mathrm{SOC}$ for those not experiencing burnout. Assumed factors which appeared to assist the development of SOC included informative politics, opportunities to participate in the workplace and the prospect to learn and develop.

\section{Interventions Studies}

These studies were those where a form of training or intervention was offered, with SOC and other factors being measure before and afterwards. ${ }^{[10,19-21]}$ The first ${ }^{[19]}$ found significant correlations between burnout, empathy, SOC, and some of the three anxiety proneness measures for Swedish community nurses. Those with a high SOC had high values on the empathy scale. The intervention appeared to have no significant effect on the results. This study had several limiting factors, namely the small size of the sample and the fact that these nurses tended to work alone. Additionally, the intervention programme was not intense and was felt to have been given over too short a period of time. The second ${ }^{[20]} \mathrm{ex}^{-}$ plored the SOC for nurses receiving clinical supervision over a one year period. They found that a strong SOC tended to act as a buffer against work related strain but did not have the same protection against dissatisfaction with working conditions or environment. They did discover that the SOC remained almost unchanged for participants throughout the intervention period, supporting Antonovsky's claim for its stability, ${ }^{[31]}$ and further suggesting that it is a factor that influences a nurse's perception of stress, not something that influences the stress itself.

Two further studies showed inconclusive results. A Japanese study ${ }^{[10]}$ measured the impact of assertiveness training amongst hospital nurses with no significant impact on the SOC. However, a Scandinavian study ${ }^{[21]}$ considered the effects of the introduction of increased dementia care information technology support, on job satisfaction. The IT support appears to have produced a positive effect on the subscale for 'meaningfulness' as well as SOC but there was no significant differences between the experimental and control group.

\section{Findings Quality}

What is clear from the review is that studies in this area tend to be methodologically idiosyncratic with a subsequent lack of general transferability. As can be seen from Table 1 sample types, sizes, research focus and correlations vary quite dramatically. Not surprisingly, polarised conclusions exist. For example, Casper ${ }^{[32]}$ posited that groups build a common SOC, which in turn influences the individual SOC of its members. Yet, other papers ${ }^{[15]}$ had previously stated that an individual's SOC developed much earlier, outside the current work situation. To add further confusion Höge and Büssing $^{[16]}$ concluded that different health job groups generated different SOC for their members, but not that these were common across either geographical sites, say, all hospitals, or professional types, such as, all PMHNs. There is an absence of empirical analysis in all these studies making the drawing of meaningful interpretations very problematic. ${ }^{[27]}$

Cilliers ${ }^{[24]}$ found significant correlation between SOC and burnout in all classes studied using the 29 item scale, whilst Levert ${ }^{[23]}$ found only two correlations (emotional exhaustion and depersonalisation) in three classes using the 13 item version. This difference cannot be accounted for through validity variance. Yet, arguing that the cultural transferability of the scales is the basis for essentially polemic results is highly questionable as all the studies included in the review show a consistent correlation with other instruments, irrespective of the country in which they were undertaken.

Further doubts concerning methodological efficacy can be found when considering the 16 cross sectional studies. It is not possible using their designs to establish the relationship 
between cause and effect, for example, does SOC influence burnout, or burnout the SOC? The SOC is designed to measure healthy alternatives but in these studies this is always achieved against a backdrop of Dis-Ease scales.

Following our initial review a modified thematic analysis was undertaken to establish both typical and atypical findings, for the sake of clarity and to be able to draw conclusions for PMHNs irrespective of where those practitioners worked. Whilst problematic this did identify factors where the SOC scales could provide information that would influence a PMHN's ability to deal with such issues as workforce stress, responsibility, roles designation, untoward incidents and employment characteristics. One outcome of this is that we were able to compare these conclusions with the extent literature and subject a degree of critical scrutiny to the work. Additionally we hoped to establish the level of falsifiability to the themed (qualitative) conclusions but had limited success because of the aberrant nature of the studies themselves. It remains unclear to us as to whether the conclusions are robust enough for Popperian science, ${ }^{[33]}$ and/or simply highlight areas where PMHNs need to focus attention for future research.

We are aware of the potential limitations of this review, i.e. the inclusion, only, of papers published in English and German and the absence of unpublished doctoral work but are satisfied that the material was adequate to achieve our objectives. Despite a careful an exhaustive search for sample papers a meta-analysis was not possible because the outcomes and settings of the studies varied too much.

\section{Implications for Psychiatric and Mental Health Nursing}

Perhaps the most effective way of establishing the significance of the review findings for PMHNs is by considering the results of the modified thematic analysis. The papers in the review covered nursing and not specifically PMHNs, but usable conclusions can be made concerning the positive correlate between an individual's SOC and their potential for burnout, a major concern within psychiatric work settings, and other disease processes, and the negative correlate between SOC and stress.

It is apparent that the SOC can be used as a predictor for the impact of stress and even burnout, by acting as a protector. However, knowing this and being able to use it are two separate things. Depending upon which theoretical construct you apply, i.e. if SOC develops before entering the work environment or afterwards, there are two different applications. If we believe that it develops prior to starting work as a PMHN then it is important during educational preparation to enable the student/nurse to appreciate their tolerances, much in the same way as we would expect to introduce them to other person-oriented skills used in day-to-day work, such as self awareness, sensitivity and locus of control. In other words, having a SOC is one thing, knowing what it is and being able to use this to counteract stressful situations, and ultimately avoid burnout, is far more meaningful. However, if we believe that the SOC develops within the work environment then firstly we need to develop an understanding of what it is and then cultivate the nurses appreciation of how it can be influenced and shaped to protect them. This second theoretical approach is perhaps more challenging because it suggests that if the developmental work is approached correctly then PMHNs are better prepared to deal with the adverse affects of burnout; but what if it is not approached correctly, or indeed, not at all. Patently, the onus of responsibility for teaching this rests with qualified practitioners, either acting as preceptors or mentors, within the work place itself, and not the classroom or lab. The challenge is therefore to find a balance between allowing newly qualified PMHNs to develop in their own right, and/or be guided through their initial developmental activities, by qualified staff who themselves understand the principles of the SOC. Logic suggests that the only way to do this is for it to be incorporated into the various preparatory syllabi. But, including it as part of clinical supervision training would appear to be more realistic.

Bearing in mind that the evidence for either theoretical approaches remains, as yet, unproven, it seems obvious to us that a combination of both the strategies described above would be the most effective way forward. By introducing the self awareness aspect during preparation and teaching practice supervisors how to cultivate it in their supervisees within the clinical areas, then all possibilities would be covered. The margin for error would be dramatically reduced and the increase in PMHN resilience and stress tolerance has to have a good chance of improving self efficacy as well care quality.

This might also have implications for dealing not only with the day-to-day events in psychiatric care settings but also the untoward incidents that could be regarded as work related trauma. Whilst there is no doubt that such events take place, having the tools and personal skills to deal with them make such happening less stressful. The study of Michael and Jenkins ${ }^{[30]}$ not only raises the question of whether or not some people are better equipped to deal with these situations naturally, i.e. that their SOC is already developed, but also whether or not it can be improved. For PMHNs this is fundamental. If, as the review suggests, a high SOC provides the individual with greater reliance, more personal skills and less stress, it follows that their ability to deal with psychiatric emergencies and/or difficult to manage situations will be more effective and keep them better protected from the corrosive impact of such events. ${ }^{[34]}$ The insidious, detrimental effects of working in a potentially volatile environment can be counteracted with a sufficiently robust SOC, no matter 
when, or how, it is acquired. The evidence from the review suggests that a low SOC not only heightens the individual's awareness of untoward events but also reduces their ability to deal with other stress provoking situations, including work practices, management issues and role definitions. The ability of the individual PMHN to deal effectively with these plays an enormous part in their clinical competence. Having no confidence in colleague support, feeling estranged from significant decision making and seeing danger and threats of violence around every therapeutic corner is hardly likely to make for a competent practitioner. Improving their level of $\mathrm{SOC}$ and/or maintaining existing high ones in others would seem to be far more beneficial for both staff and patients alike.

One final consideration in the pre/post issue is worth mentioning. Whilst accepting the possibility that group SOC, team building, leadership, workplace security and organisational frameworks, might affect the health status of PMHNs, the findings of Strümpfer ${ }^{[15]}$ and Höge ${ }^{[27]}$ cannot be ignored. They suggested that the construct of a personal SOC takes place before a nurse joins the workforce and combines with the group SOC to help deal with work-based stressors. The inference here is that the selection of candidates wishing to enter the profession takes on a new meaning. The ability to cope under stress in an occupation fraught with such pressure should be seen as a selection criterion and establishing an individual's salutogenic behaviour within the three components of the SOC would be one way of achieving this.

Any future research into the effectiveness of the SOC and its ability to guide decisions about $\mathrm{PMHNs}$ ' health promotion must consider the major issues of project design, appropriate sampling, the purpose of the SOC within the research process and clearly stated intentions of the investigation. However, it is clear from the existing studies that a clear understanding of an individual's SOC provides us with a robust method of establishing his/her ability to deal with stress within the psychiatric workplace, and, perhaps more importantly, to deal with it appropriately, professionally and effectively. Failure to address this leaves PMHNs open to the obvious criticism. If you cannot look after your self, why on earth should you be trusted with the life of others?

\section{Acknowledgement}

The research reported in this paper was carried out with financial support of the council of the von Bodelschwinghschen Anstalten Bethel.

\section{References}

1. Antonovsky A. Health, stress, and coping. San Francisco: Jossey-Bass; 1979.

2. Antonovsky A. Unraveling the mystery of health: How people manage stress and stay well. San Francisco: Jossey-Bass; 1987.
3. Antonovsky A. The structure and properties of the sense of coherence scale. Soc Sci Med 1993;36:725-33.

4. Bengel J, Strittmatter R, Willmann $\mathrm{H}$. Was erhält Menschen gesund? Antonovskys Modell der Salutogenese - Diskussionsstand und Stellenwert (Band 6). Cologne: Bundeszentrale für gesundheitliche Aufklärung; 2003.

5. Lazarus RS. Psychological stress and the coping process. New York: McGraw; 1966.

6. Aiken LH, Clarke SP, Sloane DM, Sochalski J, et al. Hospital nurse staffing and patient mortality, nurse burnout, and job dissatisfaction. JAMA 2002;288:1987-93.

7. Hasselhorn HM, Tackenberg P, Müller BH, NEXT-Study Group. Intent to leave nursing in the European nursing profession. In: Hasselhorn HM, Tackenberg $\mathrm{P}$, Müller BH. editors. Working conditions and intent to leave profession among nursing staff in Europe. Stockholm: SALTSA; 2005. p. 115-24.

8. Yam BM, Shiu AT. Perceived stress and sense of coherence among critical care nurses in Hong Kong: a pilot study. J Clin Nurs 2003;12:144-6.

9. Shiu AT. The significance of sense of coherence for the perceptions of task characteristics and stress during interruptions amongst a sample of public health nurses in Hong Kong: implications for nursing management. Public Health Nurs 1998;15:273-80.

10. Shimizu T, Kubota S, Mishima N, Nagata S. Relationship between selfesteem and assertiveness training among Japanese hospital nurses. J Occup Health 2004;46:296-8.

11. Lewis SL, Bonner PN, Campbell MA, Cooper CL, et al. Personality, stress, coping, and sense of coherence among nephrology nurses in dialysis settings. ANNA J 1994;21:325-36

12. Williams SJ. The relationship among stress, hardiness, sense of coherence, and illness in critical care nurses. Med Psychother Int J 1990;2:171-86.

13. Langius $A$, Björvell $H$, Antonovsky A. The sense of coherence concept and its relation to personality traits in Swedish samples. Scand J Caring Sci 1992;6:165-71.

14. Tselebis A, Moulou A, llias I. Burnout versus depression and sense of coherence: study of Greek nursing staff. Nurs Health Sci 2001;3:69-71.

15. Strümpfer DJW, Danana N, Gouws JF, Viviers MR. Personality dispositions and job satisfaction. SAJP 1998;2:99-100.

16. Höge $T$, Büssing $A$. The impact of sense of coherence and negative affectivity on the work stressor-strain relationship. J Occup Health Psychol 2004;9:195-205.

17. Podleiszek K, Egger JW. Quality of life in health professionals: A health psychology study with physicians, nurses, and nursing assistants. Psychologie in der Medizin 1997;2:3-7

18. Aries M, Zuppiger-Ritter I. Pflegende mit und ohne Burnout: Ein Vergleich. Resultate einer quantitativen Längsschnittuntersuchung und einer qualitativen Vertiefungsstudie. Pflege 1999;12:83-8.

19. Pålsson MB, Hallberg IR, Norberg A, Björvell H. Burnout, empathy and sense of coherence among Swedish district nurses before and after systematic clinical supervision. Scand J Caring Sci 1996;10:19-26.

20. Berg A, Hallberg IR. Effects of systematic clinical supervision on psychiatric nurses' sense of coherence, creativity, work-related strain, job satisfaction and view of the effects from clinical supervision: a pre-post test design. J Psychiatr Ment Health Nurs 1999;6:371-81.

21. Engström $M$, Ljunggren $B$, Lindqvist $R$, Carlsson $M$. Staff perceptions of job satisfaction and life situation before and 6 and 12 months after increased information technology support in dementia care. J Telemed Telecare 2005;11:304-9.

22. Kobasa SC, Maddi SR, Puccetti MC, Zola MA. Effectiveness of hardiness, exercise and social support as resources against illness. J Psychosom Res 1985;29:525-33.

23. Levert T, Marilyn L, Ortlepp K. Burnout in psychiatric nurses: Contributions of the work environment and a Sense of Coherence. SAJP 2000;2:36-43.

24. Cilliers $F$. Burnout and salutogenic functioning of nurses. Curationis 2003:26:62-74 
25. Heyns $P$ M, Venter JH, Esterhuyse KG, Bam R H, et al. Nurses caring for patients with Alzheimer's disease: Their strengths and risk of burnout. SA J Psychol 2003;33:80-5.

26. Lewis SL, Campbell MA, Becktell PJ, Cooper CL, et al. Work stress, burnout, and sense of coherence among dialysis nurses. ANNA J 1992;19:545-54.

27. Höge T. Salutogenese in der ambulanten Pflege - Zum Zusammenhang zwischen organisationalen Ressourcen, erlebter Fairness, Kohärenzsinn und der psychophysischen Gesundheit von ambulanten Pflegekräften. Zeitschrift für Gesundheitspsychologie 2005;1:3-11.

28. Leino-Loison K, Gien LT, Katajisto J, Välimäki M. Sense of coherence among unemployed nurses. J Adv Nurs 2004;48:413-22.

29. Hassmén P, Koivula N, Uutela A. Physical exercise and psychological wellbeing: a population study in Finland. Prev Med 2000;30:17-25.

30. Michael R, Jenkins HJ. Recovery from work-related trauma by periop- erative nurses: the effects of social and personal resources. Collegian 2001;8:8-13.

31. Antonovsky A. Salutogenese-Zur Entmystifizierung der Gesundheit (Deutsche erweiterte Herausgabe von Franke, A. Salutogenesis: On Demystification of Health (German Extended Edition. eds. Franke A.). Tübingen. Deutsche Gesellschaft für Verhaltenstherapie; dgvt-Verlag; 1997.

32. Casper V. Sense of Coherence-Die Kraft der Gruppe. Der Einfluss des Kohärenzgefühls einer Gruppe auf das Beanspruchungserleben ihrer Gruppenmitglieder. Münster, London: Lit-Verlag; 2005.

33. Allmark P. Popper and nursing theory. Nurse Philos 2003;4:4-16.

34. Rimann M, Udris I. Kohärenzerleben" (Sense of Coherence): Zentraler Bestandteil von Gesundheit oder Gesundheitsressource? In: Handbuch der Salutogenese. Konzept und Praxis (eds. Schüffel W, Brucks U, Johnen R.). p. 351-64. Wiesbaden: Ullstein \& Mosby; 1998. 